\title{
Effect of recipient doe genotype.on survival rate at birth of frozen rabbit embryos
}

\author{
JS Vicente, F Garciá-Ximénez \\ Departamento de Ciencia Animal, Universidad Politécnica de Valencia, 46071 Valencia, Spain
}

(Received 26 December 1992; accepted 19 March 1993)

\begin{abstract}
Summary - The effect of the genotype of 2 selected rabbit strains (White New Zealand and Synthetic) on the survival rate at birth of frozen embryos was studied. Morulae were obtained 64-66 h postcoitum from 32 multiparous does naturally mated with males of the same strain (16 does of Synthetic strain (SY) and 16 does of the White New Zealand strain (NZ)). Morphologically normal morulae were slowly frozen in $1.5 \mathrm{M}$ DMSO and stored in liquid nitrogen. After thawing, intact embryos from both strains were transferred into the oviducts of 32 recipient does of both strains (16 SY strain does and $16 \mathrm{NZ}$ does). Significant differences were observed in pregnancy rate and survival rate at birth between strains of recipient does. The recipient does of the SY strain showed a higher pregnancy rate than those of the NZ strain $(87.5 \%$ versus $25 \%$ respectively; $P<0.05)$. When the survival rate at birth was analyzed in all recipient does, this was found to be $28 \pm 4 \%$ in SY recipient does versus $8 \pm 4 \%$ in NZ recipient does $(P<0.01)$. However, when the survival rate was analyzed in pregnant recipient does, no significant differences were found between embryo strains and recipient strains, the average survival rate was $\approx 32 \%$. The major factor in the differential survival rate between $S Y$ and NZ embryos was due to the genotype of recipient does.
\end{abstract}

transfer / genotype / rabbit / frozen embryos

Résumé - Effet du génotype des lapines receveuses sur le taux de survie à la naissance des embryons congelés de lapin. On a étudié l'effet du génotype de 2 souches de lapins sélectionnées (Néozéalandais Blanc (NZ) et synthétique (SY)) sur la survie post-natale des embryons congelés. Les embryons sont récupérés aux stades de morula, vers 64-66 h post-coitum à partir de 32 lapines multipares saillies naturellement par des mâles appartenant à la même souche (NZ: 16 et SY:16). Les embryons morphologiquement normaux ont été lentement congelés dans un milieu contenant 1,5 M de DMSO et conservés dans l'azote liquide. Après décongélation, les embryons intacts, provenant des 2 souches, ont été transférés dans les oviductes de 32 lapines receveuses des 2 souches (NZ: 16 et SY: 16). Des différences significatives entre souches des lapines receveuses ont été observées pour les taux de gestation et de survie à la naissance. Les lapines receveuses de souche SY ont donné un taux de gestation plus élevé que celui de la souche NZ $187,5 \%$ contre $25 \%, \mathrm{P}<0,05)$. Quand on a analysé le taux de survie chez toutes les femelles receveuses, on trouve $28 \pm 4 \% \mathrm{chez}$ les receveuses $S Y$ et $8 \pm 4 \%$ chez les receveuses $N Z(P<0,01)$. Cependant, quand on analyse le taux de survie chez les lapines gestantes, on n'observe pas de différences significatives entre les souches d'embryons et les souches de lapines receveuses, le taux de survie 
moyen étant de 32\%. Le facteur majeur qui explique la différence entre le taux de survie des embryons $S Y$ et $N Z$ est le génotype des lapines receveuses.

transfert d'embryons / génotype / lapin / congélation

\section{INTRODUCTION}

Following the first reports of successful cryopreservation of mouse embryos (Whittingham et al, 1972; Wilmut, 1972), live offspring have been produced from frozen embryos in many other mammalian species. Efforts by several laboratories have emphasized basic cryopreservation technology and little consideration has been given to the genetic aspects of embryo cryosurvival (breed differences, variations among or within donor females, or effects of genetic selection; Pomp and Eisen, 1990).

Embryo freeze-storage is important in the management of selection nuclei to preserve selected strains from disease, to facilitate diffusion or to more accurately evaluate the genetic gain (Polge, 1977). Recently, research on cryopreservation of mouse embryos has been extended to include investigations characterizing differences in survival rate among various genetic populations (Schmidt et al, 1985, 1987; Pomp and Eisen, 1990). They indicate that both maternal and embryonic genotypes appear to affect the success of cryopreservation.

The aim of this study was to evaluate the effect of rabbit genotype of 2 selected strains (White New Zealand (NZ) and Synthetic (SY)) on the survival rate at birth of frozen embryos.

\section{MATERIAL AND METHODS}

Rabbit does of 2 selected strains were used in the experiment. The NZ strain and SY strain were selected for litter size at weaning (White
New Zealand, 14th generation and Synthetic strain, 11 th generation). These rabbit strains and selection methodologies have been described by Estany et al (1988). The NZ and SY strains used in this study differed in litter size and weight of pups at birth $(8.6 \pm 0.2$ and $10.6 \pm$ 0.3 ; and $61 \pm 0.5$ and $57 \pm 0.3 \mathrm{~g}$ - data from 100 and 119 does, respectively; unpublished observations).

Sixty-four does kept individually under the same environmental conditions ( $16 \mathrm{~h}$ light: $8 \mathrm{~h}$ dark, $20-25^{\circ} \mathrm{C}$ ) were used, 32 as embryo donors, 32 as recipient does.

Early morulae were obtained from multiparous does (SY: 16; NZ: 16) naturally mated with males of the same strain. Immediately after mating, all donor does were injected iv with a dose of 25 IU hCG (Coriogan, Overjero). Does were killed $64-65 \mathrm{~h}$ after mating. The reproductive tract was immediately removed and morulae were recovered by flushing each oviduct at room temperature with $3 \mathrm{ml}$ Dulbecco's phosphate-buffered saline supplemented with $20 \%$ heat-inactivated rabbit serum. Rabbit serum was obtained from donor does after slaughter 64$66 \mathrm{~h}$ post-coitum (hpc). The blood clot was removed and the serum centrifuged at $3000 \mathrm{rpm}$ for $10 \mathrm{~min}$, then stored at $-30^{\circ} \mathrm{C}$. Before use, it was inactivated in a $56^{\circ} \mathrm{C}$ water-bath for $30 \mathrm{~min}$ and sterilized by microfiltration $(0.22 \mu \mathrm{m}$ pore size). Ovulation rate (estimated from the number of partially-formed corpora lutea), number of recovered embryos and normal embryos were recorded

The embryos were washed once in PBS + $20 \%$ heat-inactivated rabbit serum at room temperature and scored according to morphological criteria (Hafez, 1987). Only normal morulae were frozen. The freezing and thawing procedures have been described in previous studies (Garcia-Ximénez and Vicente, 1991; Vicente and Garcia-Ximénez, 1993). Embryos were frozen in $1.5 \mathrm{M}$ DMSO by a slow freezing program and thawed in air at room temperature $\left(20^{\circ} \mathrm{C}\right)$.

Normal thawed embryos from 1 donor doe were transferred into the oviduct of a pseudo- 
pregnant nulliparous doe (SY : 16; NZ : 16) which had received an iv injection of $25 \mathrm{IU}$ hCG $48 \mathrm{~h}$ before transfer (Tsunoda et al, 1982; Garcia-Ximénez and Vicente, 1991). The recipient does were anaesthetized by im injection of $5: 1$ ketamine chlorhydrate (ketolar $50 \mathrm{mg} / \mathrm{ml}$, ParkeDavis) prometazine (Phenergan $25 \mathrm{mg} / \mathrm{ml}$, Rhone-Poulenc) solution $(1.2 \mathrm{ml} / \mathrm{kg}$ body weight) followed 5 min later by iv injection of 1.5 $\mathrm{ml}$ of the same solution in the marginal ear vein. Transfers were carried out by midline ventral laparotomy.

Each recipient doe hosted embryos from 1 donor doe ( 8 to 12 embryos). A balanced procedure of homologous and heterologous transfers was carried out. In the recipient does which became pregnant the survival rate of frozen embryos was evaluated at birth.

\section{Data analysis}

In agreement with the findings of Pomp and Eisen (1990) the variations in donor does were taken into consideration, so the analyses of post-thaw survival were performed on data from individual donor does, which led to a more conservative test of genotypic differences. On the other hand, from a genetic point of view, in establishing a control group, the number of donor does with offspring and offspring identification are important.

Data from survival rate at birth for each donor doe (number of live pups/number of transferred embryos) after arcsin transformation were analyzed by a 2-way analysis of variance to determine whether a significant interaction existed between the factors: genetic strain of embryos and recipient does. A protected least significant difference test was used to compare means of survival rate.

Ovulation rate and number of recovered normal embryos were analyzed by analysis of variance.

\section{RESULTS}

No significant differences were observed in ovulation rate (SY: $14.0 \pm 0.6, \mathrm{NZ}: 13.4 \pm$ $0.6)$ and in the number of recovered nor- mal embryos (SY: $10.3 \pm 0.6$; NZ: $10.6 \pm$ $0.5)$ between the strains in the experiment.

After slow freezing-thawing of embryos in $1.5 \mathrm{M} \mathrm{DMSO}, 96 \%$ (323/335) of total frozen morulae in both strains were catalogued as transferable.

Significant differences were observed in the pregnancy rate between strains of recipient does. The recipient does of the SY strain showed a higher pregnancy rate than those of the NZ strain $(87.5 \%, 14 / 16$ versus $25 \%, 4 / 16$ respectively; $P<0.05$ ). No differences were found in pregnancy rate between embryo strains $(56 \%, 9 / 16)$.

Table I shows the mean number of embryos transferred and the survival rate at birth both overall and in pregnant recipient does.

When the survival rate at birth was analyzed for all recipient does, significant differences were observed between recipient strains ( $28 \pm 4 \%$ versus $8 \pm 4 \%$, SY and NZ strains respectively, $P<0.01$, table I). By contrast, no significant differences were detected between embryo strains (table I). The mean survival rate of pregnant recipient does was $32 \pm 3 \%$.

Interaction between the main factors (embryo and recipient strains) was not significant $(P>0.05)$.

\section{DISCUSSION}

In a previous study when frozen morulae of the SY and NZ strains were transferred into recipient does of the same strain (homologous transfer), a slight differential survival rate at birth was observed $(24 \pm 4 \%$ versus $12 \pm 4 \%$; Garcia-Ximénez and Vicente, 1992). In the present study we demonstrated that a major factor in differential survival rate of frozen embryos between SY and NZ embryos was the genotype of recipient does. When NZ and SY embryos were transferred to $S Y$ recipient 
Table I. Survival rate at birth of frozen embryos in terms of recipient and embryonic genotype.

\begin{tabular}{|c|c|c|c|c|c|c|c|c|c|}
\hline & \multicolumn{3}{|c|}{ SY strain } & \multicolumn{3}{|c|}{$\begin{array}{r}\text { Recipient does } \\
N Z \text { strain }\end{array}$} & \multicolumn{3}{|c|}{ Total } \\
\hline & Does & $\begin{array}{l}\text { Transferred } \\
\text { embryos }\end{array}$ & $\begin{array}{l}\text { Survival } \\
\text { rate (\%) }\end{array}$ & Does & $\begin{array}{l}\text { Transferred } \\
\text { embryos }\end{array}$ & $\begin{array}{l}\text { Survival } \\
\text { rate }(\%)\end{array}$ & Does & $\begin{array}{l}\text { Transferred } \\
\text { embryos }\end{array}$ & $\begin{array}{l}\text { Survival } \\
\text { rate (\%) }\end{array}$ \\
\hline SY & 8 & $\begin{array}{l}9.9 \pm 0.6 \\
(79)\end{array}$ & $\begin{array}{c}30 \pm 5 \\
(24)\end{array}$ & 8 & $\begin{array}{l}10.1 \pm 0.6 \\
(81)\end{array}$ & $\begin{array}{l}7 \pm 5 \\
(6)\end{array}$ & 16 & $\begin{array}{c}10.0 \pm 0.4 \\
(160)\end{array}$ & $\begin{array}{c}19 \pm 5 \\
(30)\end{array}$ \\
\hline$N Z$ & 8 & $\begin{array}{c}10.4 \pm 0.7 \\
(83)\end{array}$ & $\begin{array}{c}25 \pm 6 \\
(21)\end{array}$ & 8 & $\begin{array}{l}10.0 \pm 0.6 \\
\quad(80)\end{array}$ & $\begin{array}{c}9 \pm 6 \\
(7)\end{array}$ & 16 & $\begin{array}{l}10.2 \pm 0.5 \\
\quad(163)\end{array}$ & $\begin{array}{l}17 \pm 5 \\
(28)\end{array}$ \\
\hline \multirow[t]{3}{*}{ Total } & 16 & $\begin{array}{l}10.1 \pm 0.5 \\
\quad(162)\end{array}$ & $\begin{array}{c}28 \pm 4^{a} \\
(45)\end{array}$ & 16 & $\begin{array}{l}10.0 \pm 0.4 \\
(161)\end{array}$ & $\begin{array}{c}8 \pm 4^{6} \\
(13)\end{array}$ & 32 & $\begin{array}{l}10.1 \pm 0.3 \\
(323)\end{array}$ & $\begin{array}{l}18 \pm 3 \\
(58)\end{array}$ \\
\hline & \multicolumn{6}{|c|}{$\begin{array}{l}\text { Pregnant recipient does } \\
\text { NZ strain }\end{array}$} & \multicolumn{3}{|c|}{ Total } \\
\hline & Does & $\begin{array}{l}\text { Transferred } \\
\text { embryos }\end{array}$ & $\begin{array}{l}\text { Survival } \\
\text { rate (\%) }\end{array}$ & Does & $\begin{array}{c}\text { Transferred } \\
\text { embryos }\end{array}$ & $\begin{array}{l}\text { Survival } \\
\text { rate (\%) }\end{array}$ & Does & $\begin{array}{l}\text { Transferred } \\
\text { embryos }\end{array}$ & $\begin{array}{l}\text { Survival } \\
\text { rate (\%) }\end{array}$ \\
\hline SY & 7 & $\begin{array}{c}9.7 \pm 0.7 \\
(68)\end{array}$ & $\begin{array}{c}35 \pm 4 \\
(24)\end{array}$ & 2 & $\begin{array}{l}9.5 \pm 1.5 \\
(19)\end{array}$ & $\begin{array}{c}32 \pm 10 \\
(6)\end{array}$ & 9 & $\begin{array}{c}9.7 \pm 0.6 \\
(87)\end{array}$ & $\begin{array}{c}34 \pm 4 \\
(30)\end{array}$ \\
\hline$N Z$ & 7 & $\begin{array}{c}10.3 \pm 0.9 \\
(72)\end{array}$ & $\begin{array}{c}29 \pm 4 \\
(21)\end{array}$ & 2 & $\begin{array}{l}10.5 \pm 1.5 \\
(21)\end{array}$ & $\begin{array}{c}33 \pm 10 \\
(7)\end{array}$ & 9 & $\begin{array}{c}10.3 \pm 1.0 \\
(93)\end{array}$ & $\begin{array}{c}30 \pm 3 \\
(28)\end{array}$ \\
\hline Total & 14 & $\begin{array}{c}10.0 \pm 0.8 \\
(140)\end{array}$ & $\begin{array}{c}32 \pm 3 \\
(45)\end{array}$ & 4 & $\begin{array}{c}10.0 \pm 0.9 \\
(40)\end{array}$ & $\begin{array}{c}32 \pm 6 \\
(13)\end{array}$ & 18 & $\begin{array}{l}9.9 \pm 0.8 \\
(180)\end{array}$ & $\begin{array}{c}32 \pm 3 \\
(58)\end{array}$ \\
\hline
\end{tabular}

Mean \pm SEM; ( ) total number of transferred embryos and total number of live pups; survival rate (\%): number of live pups/number of transferred embryos per recipient doe; ${ }^{\text {a.b }}$ values with different superscript are statistically different $(P<0.01)$

does, the pregnancy rate was higher than in NZ recipient does ( $87.5 \%$ versus $25 \%$ ). In addition, survival rate was improved in both embryo strains when they were transferred to recipient does of the SY strain, attaining $28 \%$ versus $8 \%$ in recipient does of the NZ strain.

This difference in recipient ability to maintain the development of transferred embryos could be due to a differential maternal ability and/or a different level of sensitivity to the transfer procedure. In spite of the fact that these strains did not show any differences in ovulation rate, percentage of recovered normal embryos or percentage of transferable embryos, in a previous study we did observe differences in mucin coat thickness, thus showing different total diameter of morulae belonging to these strains (data from 100 64-66 h hpc morulae of each strain: $340 \pm 4 \mu \mathrm{m}$ for NZ embryos and $374 \pm 5 \mu \mathrm{m}$ for SY embryos; $\mathrm{Vi}$ cente, 1991). This coat is mainly of oviductal origin. Moreover, in these same 
strains, Molina (1987) has observed an increased development of $96 \mathrm{hpc}$ blastocysts from both strains when transferred to SY recipients than when they were transferred than NZ strain. Furthermore, this author has observed that blastocyst diameters (with or without the mucin coat) are greater in the SY strain than in the NZ strain. There appear to be differences in the oviductal and uterine environments of the SY and NZ does.

In 2 rabbit strains also selected for litter size, Torrès et al (1986) have observed that the uterine environment of the California strain gives rise to a lower number of fertilized oocytes and a smaller embryo development than that of the NZ strain. Maurer et Haseman (1976) have observed a higher percentage of survival in DutchBelted embryos than in NZ White embryos ( $20 \%$ versus $7 \%$ ), while a higher percentage of embryos, irrespective of their genotype and whether they had been frozen, developed in NZ White recipient does than in Dutch-Belted recipient does (46\% versus $26 \%$ ). Differences in survival rate of freezing-thawing stress have recently been observed in mouse strains (Schmidt et al, 1985, 1987; Pomp and Eisen, 1990). Pomp and Eisen (1990) have found an opposite influence on survival rate between maternal and embryo genotype.

On the other hand, another factor that affects the outcome of the transfer is the tolerance of embryos to transfer, which is related to the developmental stage (Bolet and Theau-Clement, 1988; in rabbit) and embryo genotype (Ashworth et al, 1990; in pig).

It appears that the difference found in survival rate of frozen embryos was due in some cases to factors which are independent of the freezing-thawing programme and which are mainly related to the recipient does. Thus, the same freezing programme could be used in different strain by only changing the transfer strategy for these embryos, rather than having to establish individual freezing regimens for each strain.

In conclusion, the survival rate of frozen embryos of the NZ strain increased when they were transferred to recipient does of the SY strain. In this case a pregnancy rate of $87.5 \%$ and a survival rate of $32 \%$ at birth were obtained.

\section{ACKNOWLEDGMENT}

This study was supported by CICYT GAN 90 0632.

\section{REFERENCES}

Adams CE (1982) Mammalian Egg Transfer. CRC Press, Boca Raton, FL, 29-48

Ashworth CJ, Haley CS, Aitken RP, Wilmut I (1990) Embryo survival and conceptus growth after reciprocal transfer between $\mathrm{Chi}$ nese Meishan and Landrace $\times$ Large White gilts. J Reprod Fertil 90, 595-603

Bolet G, Theau-Clement M (1988) Timing of embryonic development in two rabbit strains. In: 11th int Congr Anim Reprod Artific Insemin. Dublin, Eire, 3, 391-393

Estany J, Baselga M, Blasco A, Camacho J (1988) Mixed model methodology for the estimation of genetic response to selection in litter size of rabbits. Livest Prod Sci 21, 67-75

Garcia-Ximénez F, Vicente JS (1991) Postimplantational survival of frozen-thawed rabbit morulae relative to the site of transfer and ovulation time of recipients. J Appl Rabbit Res 14 (3), 155-158

Garcia-Ximenez F, Vicente JS (1992) Effect of ovarian cystic or haemorrhagic follicles on embryo recovery and survival after transfer in hCG-ovulated rabbits. Nutr Reprod Dev 32, 143-149

Hafez ESE (1987) Reproduction in Farm Animals. Lea and Febiger, Philadelphia, 5th edn, 571-600

Maurer RR, Haseman JK (1976) Freezing morula stage rabbit embryos. Biol Reprod 14, 256-263

Molina 1 (1987) Determinación de los efectos genéticos directos y maternos sobre la tasa de 
ovulación y la viabilidad embrionaria y fetal en el conejo, mediante la aplicación de las técnicas de transferencia de embriones y laparoscopia. Tesis Doctoral, Fac CC Biol, Univ Valencia

Polge C (1977) The freezing of mammalian embryos: perspectives and possibilities. In: The Freezing of Mammalian Embryos. Ciba Found Symp, New Ser 52, 3-13

Pomp D, Eisen EJ (1990) Genetic control of survival of frozen mouse embryos. Biol Reprod 42, 775-786

Schmidt PM, Hansen CT, Wildt DE (1985) Viability of frozen-thawed mouse embryos is affected by genotype. Biol Reprod 32, 507-514

Schmidt PM, Schiewe MC, Wildt DE (1987) The genotypic response of mouse embryos to multiple freezing variables. Biol Reprod 37, 1121-1128

Torrès S, Hulot F, Meunier M (1986) Etude comparée du développement et de la mortalité embryonnaire chez deux génotypes de lapines. In: $4^{e s}$ Journ Rech Cunicole. Paris, 417-425
Tsunoda Y, Sugie T (1977) Survival of rabbit eggs preserved in plastic straws. J Reprod Fertil 49, 173-174

Tsunoda $Y$, Soma T, Sugie $T$ (1982) Effect of post-ovulatory age of recipient on survival of frozen-thawed rabbit morulae. $J$ Reprod Fertil $65,483-487$

Vicente JS (1991) Programa de Crioconservacion de mórulas de conejo. Tesis Doctoral, Univ Politécnica, Valencia

Vicente JS, Garcia-Ximénez F (1993) Effects of strain and embryo transfer model (embryo from one vs two donor does/recipient) on results of cryopresenvation in rabbit. Reprod Nutr Dev 33, 1-5

Whittingham DG, Leibo SP, Mazur P (1972) Survival of mouse embryos frozen to $-196{ }^{\circ} \mathrm{C}$ and $-269^{\circ} \mathrm{C}$. Science $178,411-414$

Wilmut I (1972) The effects of cooling rate, warming rate, cryoprotective agent and stage of development on survival of mouse embryos during freezing and thawing. Life Sci 11, 1071-1079 